\title{
Tiotropium add-on therapy is safe and reduces seasonal worsening in paediatric asthma patients
}

\author{
Christian Vogelberg ${ }^{1}$, Stanley J. Szefler ${ }^{2}$, Elianne J.L.E. Vrijlandt ${ }^{3}$, \\ Attilio L. Boner ${ }^{4}$, Michael Engel ${ }^{5}$, Georges El Azzi ${ }^{5}$, Sebastian Dan Vulcu ${ }^{5}$, \\ Petra M. Moroni-Zentgraf ${ }^{6}$, Olaf Eickmeier ${ }^{7}$ and Eckard H. Hamelmann ${ }^{8}$
}

@ERSpublications

Once-daily tiotropium Respimat add-on therapy is safe in paediatric patients and reduces adverse events related to asthma exacerbations and symptoms, especially during seasonal peaks http://ow.ly/ ujHw30of3xk

Cite this article as: Vogelberg C, Szefler SJ, Vrijlandt EJLE, et al. Tiotropium add-on therapy is safe and reduces seasonal worsening in paediatric asthma patients. Eur Respir J 2019; 53: 1801824 [https://doi. org/10.1183/13993003.01824-2018].

ABSTRACT There remains an unmet need for effective, well-tolerated therapeutic options in paediatric patients with not fully controlled asthma, for whom safety is of paramount importance.

Data were pooled from five randomised, double-blind, placebo-controlled studies evaluating tiotropium 5 or $2.5 \mu \mathrm{g}$ versus placebo add-on therapy in patients with symptomatic asthma aged 1-17 years. Analysis included adverse events (AEs) and serious AEs (SAEs) reported throughout and for 30 days following treatment.

Of 1691 patients treated, 1119 received tiotropium. Reporting of AEs was low and comparable across all groups: tiotropium $5 \mu \mathrm{g}$ (51\%), tiotropium $2.5 \mu \mathrm{g}$ (51\%) and placebo (54\%). Reporting of drug-related AEs, those leading to discontinuation and SAEs was also low and balanced between treatment groups, irrespective of age, disease severity or sex. The number of AEs related to asthma symptoms and exacerbations was lower with tiotropium $(5 \mu \mathrm{g})$ than with placebo, particularly during the seasonal peaks of these AEs.

This comprehensive analysis of a large safety database allowed subgroup analyses that are often impractical with individual trials and provides further support for the safety of once-daily tiotropium Respimat add-on therapy in paediatric patients with symptomatic asthma.

This article has supplementary material available from erj.ersjournals.com

ClinicalTrials.gov registration details: NinoTinA-asthma, NCT01634113; CanoTinA-asthma, NCT01634139; VivaTinAasthma, NCT01634152; RubaTinA-asthma, NCT01257230; PensieTinA-asthma, NCT01277523. To ensure independent interpretation of clinical study results, Boehringer Ingelheim grants all external authors access to all relevant material, including participant-level clinical study data, and relevant material as needed by them to fulfil their role and obligations as authors under the ICMJE criteria. Furthermore, clinical study documents (e.g. study report, study protocol, statistical analysis plan) and participant clinical study data are available to be shared after publication of the primary manuscript in a peer-reviewed journal and if regulatory activities are complete and other criteria met per the Boehringer Ingelheim Policy on Transparency and Publication of Clinical Study Data: https://trials.boehringeringelheim.com/transparency_policy.html. Prior to providing access, documents will be examined, and, if necessary, redacted and the data will be de-identified, to protect the personal data of study participants and personnel, and to respect the boundaries of the informed consent of the study participants. Clinical study reports and related clinical documents can be requested via: https://trials.boehringer-ingelheim.com/trial_results/clinical_submission_documents. html. All such requests will be governed by a document sharing agreement. Bona fide, qualified scientific and medical researchers may request access to de-identified, analysable participant clinical study data with corresponding documentation describing the structure and content of the datasets. Upon approval, and governed by a data sharing agreement, data are shared in a secured data access system for a limited period of 1 year, which may be extended upon request. Researchers should use https://clinicalstudydatarequest.com to request access to study data.

Received: Sept 262018 | Accepted after revision: March 192019

Copyright OERS 2019. This version is distributed under the terms of the Creative Commons Attribution NonCommercial Licence 4.0. 


\section{Introduction}

Asthma is one of the most prevalent chronic diseases in children and adolescents, affecting $\sim 10 \%$ of children and adolescents in the UK and USA [1-3]. Studies have shown that $>50 \%$ of $4-18$-year-old patients with asthma remain symptomatic despite treatment with at least an inhaled corticosteroid (ICS) $[1,2]$. For these patients, the first intervention is to improve patient education and self-management. This involves ensuring adherence to the prescribed treatment and optimal use of the device, and, where possible, confirming the avoidance of allergens and exposure to environmental pollutants and tobacco smoke. Should symptoms persist, step-up treatments may be considered. Treatment options include addition of a long-acting $\beta_{2}$-agonist (LABA) and/or a leukotriene receptor antagonist (LTRA) to the maintenance treatment regimen and/or a further increase in the dose of ICS [4]. ICS therapy is shown to affect growth in children, particularly when administered in medium-to-high doses over an extended period of time; thus, an alternative to increasing the ICS dose would be attractive $[5,6]$. Common side-effects associated with LABAs include increased heart rate, palpitations and tremor, although tremor commonly resolves after the first few doses [7]. The LTRA montelukast has generally been regarded as safe for use in children, although inferior to ICS in terms of efficacy [8]. Conversely, a study utilising the Swedish database for adverse drug reactions, SWEDIS, which investigated drug groups commonly used in children, has shown that montelukast was the drug with the most frequent adverse drug reactions in 2005. The majority of these were in children $<5$ years old and were predominately psychiatric in nature [9]. Another study has also highlighted some specific neuropsychiatric adverse events (AEs), of which users should be cognisant [10]. Therefore, there is an unmet need for more well-tolerated and efficacious therapeutic options for the treatment of paediatric patients with symptomatic asthma.

Tiotropium Respimat (Boehringer Ingelheim, Ingelheim am Rhein, Germany) (hereafter referred to as "tiotropium") is a long-acting muscarinic antagonist. It has been evaluated as an add-on therapy in a comprehensive phase 2 and 3 clinical trial programme including more than 6000 adult and paediatric patients with symptomatic asthma [11-24]. Based on the evidence from these trials, tiotropium is an efficacious add-on therapy, with safety and tolerability comparable with placebo in the individual studies. Tiotropium is indicated for once-daily use in the European Union (two inhalations of $2.5 \mu \mathrm{g}$ ) and USA (two inhalations of $1.25 \mu \mathrm{g}$ ) as maintenance treatment in patients with severe asthma aged $\geqslant 6$ years $[25,26]$. In addition to the safety reports of tiotropium add-on therapy from the individual clinical trials, and an in-depth, systematic assessment of safety and tolerability in adult patients $[27,28]$, the analysis presented here, involving a large sample of paediatric patients, can provide greater power to detect any as-yet unidentified safety signals, and allows the analysis of safety in subgroups that is impractical with individual trials.

The aim of the current analysis, therefore, was to further assess the safety and tolerability of tiotropium from a pooled population of paediatric (1-17 years) patients with symptomatic asthma at different Global Initiative for Asthma (GINA) treatment steps, and to investigate the seasonality of AEs relating to asthma exacerbations and symptoms in the pooled populations.

\section{Methods}

This pooled analysis included all phase 3 parallel-group studies in children (6-11 years) and adolescents (12-17 years), as well as a phase $2 / 3$ study in children aged $1-5$ years, included in the clinical development programme of tiotropium in asthma. All trials were of randomised, double-blind, placebo-controlled design, and between 12 weeks and 1 year in duration (table 1) [18, 19, 21-23]. The treatment history (treatment step on enrolment) specified in each trial differed and reflected the severity of the patient population (table 1).

Affiliations: ${ }^{1}$ Dept of Pediatric Pulmonology and Allergy, University Hospital Carl Gustav Carus, Technical University of Dresden, Dresden, Germany. ${ }^{2}$ Children's Hospital of Colorado and the University of Colorado Denver School of Medicine, Aurora, CO, USA. ${ }^{3}$ Dept of Pediatric Pulmonology and Pediatric Allergy, Beatrix Children's Hospital, University Medical Center Groningen, University of Groningen, Groningen, The Netherlands. ${ }^{4}$ UOC di Pediatria, Dipartimento di Scienze Chirurgiche Odontostomatologiche e Materno Infantili, Policlinico "G. Rossi", Verona, Italy. ${ }^{5}$ Boehringer Ingelheim International GmbH, Ingelheim am Rhein, Germany. ${ }^{6}$ Boehringer Ingelheim Pty Ltd, Sydney, Australia. ${ }^{7}$ Dept of Pediatric Allergology, Pulmonology and Cystic Fibrosis, University Children's Hospital, Goethe University, Frankfurt, Germany. ${ }^{8}$ Klinik für Kinder- und Jugendmedizin, Evangelisches Klinikum Bethel, Bielefeld and Allergy Center of the Ruhr University, Bochum, Germany.

Correspondence: Christian Vogelberg, Dept of Pediatric Pulmonology and Allergy, University Hospital Carl Gustav Carus, Technical University of Dresden, Fetscherstraße 74, 01307 Dresden, Germany.

E-mail: christian.vogelbergQuniklinikum-dresden.de 
TABLE 1 Overview of study designs and key inclusion/exclusion criteria

\begin{tabular}{|c|c|c|c|c|c|}
\hline & NinoTinA-asthma [23] & CanoTinA-asthma [21] & VivaTinA-asthma [20] & RubaTinA-asthma [17] & PensieTinA-asthma [18] \\
\hline $\begin{array}{l}\text { ClinicalTrials.gov } \\
\text { identifier }\end{array}$ & NCT01634113 & NCT01634139 & NCT01634152 & NCT01257230 & NCT01277523 \\
\hline Phase and design ${ }^{\#}$ & Phase $2 / 3$ & $\begin{array}{c}\text { Phase 3, randomised, } \\
\text { double-blind, placebo-controlled, } \\
\text { parallel-group }\end{array}$ & $\begin{array}{l}\text { Phase 3, randomised, double-blind, } \\
\text { placebo-controlled, parallel-group }\end{array}$ & $\begin{array}{c}\text { Phase 3, randomised, } \\
\text { double-blind, placebo-controlled, } \\
\text { parallel-group }\end{array}$ & $\begin{array}{l}\text { Phase 3, randomised, double-blind, } \\
\text { placebo-controlled, parallel-group }\end{array}$ \\
\hline Objectives & Efficacy and safety & Efficacy and safety & Efficacy and safety & Efficacy and safety & Efficacy and safety \\
\hline Patient population & $\begin{array}{l}\text { 1-5-year-olds with persistent } \\
\text { asthmatic symptoms }\end{array}$ & $\begin{array}{l}\text { 6-11-year-olds with symptomatic } \\
\text { moderate asthma }\end{array}$ & $\begin{array}{c}\text { 6-11-year-olds with symptomatic } \\
\text { severe asthma }\end{array}$ & $\begin{array}{l}\text { 12-17-year-olds with } \\
\text { symptomatic moderate asthma }\end{array}$ & $\begin{array}{l}\text { 12-17-year-olds with symptomatic } \\
\text { severe asthma }\end{array}$ \\
\hline History of asthma & NA & $\geqslant 6$ months & $\geqslant 6$ months & $\geqslant 3$ months & $\geqslant 3$ months \\
\hline Symptomatic asthma & $\begin{array}{l}\text { Daytime symptoms more than } \\
\text { twice a week; any limitation of } \\
\text { activities; any nocturnal } \\
\text { symptoms/awakenings; need } \\
\text { for rescue medication } \\
\quad>2 \text { days.week }\end{array}$ & $A C Q-\mid A \geqslant 1.5$ & $A C Q-\mid A \geqslant 1.5$ & $A C Q \geqslant 1.5$ & $A C Q \geqslant 1.5$ \\
\hline $\begin{array}{l}\text { Minimum asthma } \\
\text { controller } \\
\text { medication }\end{array}$ & $\begin{array}{l}\text { Stable ICS, with or without } \\
\text { another controller, for } \\
\geqslant 4 \text { weeks before screening }\end{array}$ & $\begin{array}{c}\text { Medium-dose ICS (200- } \\
400 \mu \mathrm{g}^{\text {day }}{ }^{-1} \text { budesonide or } \\
\text { equivalent dose), with or without } \\
\text { another controller, for } \geqslant 4 \text { weeks } \\
\text { before screening; LABA had to be } \\
\text { discontinued } \geqslant 24 \mathrm{~h} \text { prior to } \\
\text { screening }\end{array}$ & $\begin{array}{l}\text { High-dose ICS ( }>400 \mu \mathrm{g} \cdot \text { day }^{-1} \\
\text { budesonide or equivalent dose) plus } \\
\geqslant 1 \text { controller or medium-dose ICS } \\
\left(200-400 \mu \mathrm{g} \cdot \text { day }^{-1} \text { budesonide or }\right. \\
\text { equivalent dose) plus } \geqslant 2 \text { controllers } \\
\text { for } \geqslant 4 \text { weeks before screening }\end{array}$ & $\begin{array}{l}\text { Medium-dose ICS }(400- \\
800 \mu \mathrm{g} \cdot \text { day }^{-1} \text { budesonide or } \\
\text { equivalent dosel, with or without } \\
\text { LTRA, for } \geqslant 4 \text { weeks before } \\
\text { screening; LABA had to be } \\
\text { discontinued } \geqslant 72 \text { h prior to } \\
\text { screening }\end{array}$ & $\begin{array}{l}\text { High-dose ICS ( } 800-1600 \mu \mathrm{g} \cdot \text { day }^{-1} \\
\text { budesonide or equivalent dose) plus } \\
\geqslant 1 \text { controller or medium-dose ICS } \\
\left(400-800 \mu \mathrm{g} \cdot \text { day }^{-1} \text { budesonide or }\right. \\
\text { equivalent dose) plus } \geqslant 2 \text { controllers } \\
\text { for } \geqslant 4 \text { weeks before screening }\end{array}$ \\
\hline $\begin{array}{l}\text { Pre-bronchodilator } \\
\text { FEV } \% \text { pred at } \\
\text { screening }\end{array}$ & $\leqslant 90 \%$ for 5 -year-olds & $60-90 \%$ & $60-90 \%$ & $60-90 \%$ & $60-90 \%$ \\
\hline $\begin{array}{l}\text { FEV } 1 \text { reversibility at } \\
\text { screening }\end{array}$ & & $\begin{array}{l}\geqslant 12 \%, 15-30 \text { min after } 200 \mu \mathrm{g} \\
\quad \text { salbutamol }\end{array}$ & $\begin{array}{l}\geqslant 12 \%, 15-30 \text { min after } 200 \mu \mathrm{g} \\
\quad \text { salbutamol }\end{array}$ & $\begin{array}{l}\geqslant 12 \% \text { and } \geqslant 200 \mathrm{~mL}, 15-30 \mathrm{~min} \\
\text { after } 400 \mu \mathrm{g} \text { salbutamol lage } \\
>14 \text { years) or } \geqslant 12 \% \text { only lage } 12- \\
\quad 14 \text { years) }\end{array}$ & $\begin{array}{c}\geqslant 12 \% \text { and } \geqslant 200 \mathrm{~mL}, 15-30 \text { min after } \\
400 \mu \mathrm{g} \text { salbutamol (age }>14 \text { years) or } \\
\geqslant 12 \% \text { only (age } 12-14 \text { years) }\end{array}$ \\
\hline $\begin{array}{l}\text { Variability of absolute } \\
\text { FEV from screening } \\
\text { to randomisation }\end{array}$ & & $\pm 30 \%$ & $\pm 30 \%$ & $\pm 30 \%$ & $\pm 30 \%$ \\
\hline Smoking history & & & & $\begin{array}{c}\text { Nonsmoker or ex-smoker who } \\
\text { stopped smoking } \geqslant 1 \text { year prior to } \\
\text { enrolment }\end{array}$ & $\begin{array}{c}\text { Nonsmoker or ex-smoker who } \\
\text { stopped smoking } \geqslant 1 \text { year prior to } \\
\text { enrolment }\end{array}$ \\
\hline Exclusion criteria & $\begin{array}{c}\text { Significant disease other than } \\
\text { asthma }\end{array}$ & $\begin{array}{c}\text { Significant disease other than } \\
\text { asthma }\end{array}$ & $\begin{array}{l}\text { Significant disease other than } \\
\text { asthma }\end{array}$ & $\begin{array}{c}\text { Significant disease other than } \\
\text { asthma }\end{array}$ & $\begin{array}{l}\text { Significant disease other than } \\
\text { asthma }\end{array}$ \\
\hline Treatment & $\begin{array}{c}\text { Once-daily tiotropium }(5 \text { or } \\
2.5 \mu \mathrm{g} \text { ) or placebo }{ }^{+}\end{array}$ & $\begin{array}{l}\text { Once-daily tiotropium (5 or } 2.5 \mu \mathrm{g}) \\
\text { or placebo }\end{array}$ & $\begin{array}{l}\text { Once-daily tiotropium ( } 5 \text { or } 2.5 \mu \mathrm{g} \text { ) } \\
\text { or placebo }\end{array}$ & $\begin{array}{c}\text { Once-daily tiotropium (5 or } \\
2.5 \mu \mathrm{g} \text { ) or placebo }\end{array}$ & $\begin{array}{c}\text { Once-daily tiotropium ( } 5 \text { or } 2.5 \mu \mathrm{g} \text { ) or } \\
\text { placebo }\end{array}$ \\
\hline Treatment duration & 12 weeks & 48 weeks & 12 weeks & 48 weeks & 12 weeks \\
\hline Sample size & $\begin{array}{l}102 \text { randomised patients (101 } \\
\text { treated, } 102 \text { planned); } 101 \\
\text { completed patients }\end{array}$ & $\begin{array}{l}403 \text { randomised patients ( } 401 \\
\text { treated, } 385 \text { planned); } 384 \\
\text { completed patients }\end{array}$ & $\begin{array}{l}401 \text { randomised patients ( } 400 \\
\text { treated, } 375 \text { planned); } 392 \\
\text { completed patients }\end{array}$ & $\begin{array}{l}398 \text { randomised patients (397 } \\
\text { treated, } 127 \text { planned per group); } \\
376 \text { completed patients }\end{array}$ & $\begin{array}{c}392 \text { randomised patients }(392 \\
\text { treated, } 375 \text { planned); } 388 \text { completed } \\
\text { patients }\end{array}$ \\
\hline \multicolumn{6}{|c|}{$\begin{array}{l}\text { NA: not applicable; ACQ: Asthma Control Questionnaire; IA: interviewer-administered; ICS: inhaled corticosteroid; LTRA: leukotriene receptor antagonist; LABA: long-acting } \beta_{2} \text {-agonist } \\
\text { FEV1: forced expiratory volume in } 1 \mathrm{~s} ; \% \text { pred: } \% \text { predicted. } \#: \text { note that NinoTinA-asthma was a phase } 2 / 3 \text { trial; }{ }^{\eta}: \text { the study allowed variation of absolute FEV } 1 \text { values for visit } 1 \\
\text { (pre-bronchodilator) compared with visit } 2 \text { (pre-dose) within } \pm 30 \%{ }^{+}: \text {in the NinoTinA-asthma study, patients aged } 1-4 \text { years at visit } 1 \text { were required to use an Aerochamber Plus Flow-Vu } \\
\text { valved holding chamber (commonly referred to as a spacer) with a face mask for the inhalation of trial medication to reduce variability and ensure standardised dosing, whereas children } \\
\text { aged } 5 \text { years at visit } 1 \text { were permitted to use the Respimat without a spacer (overall three patients did not use a spacer). }\end{array}$} \\
\hline
\end{tabular}




\section{Trial medication}

During the treatment period in all trials, patients received tiotropium ( 5 or $2.5 \mu \mathrm{g}$ ) or placebo (delivered by a Respimat inhaler as two puffs) once daily. Tiotropium was administered as add-on therapy to ICS maintenance treatment with or without other controller therapies. In the NinoTinA-asthma study [23], patients aged 1-4 years at screening were required to use an Aerochamber Plus Flow-Vu valved holding chamber (commonly referred to as a spacer; Trudell Medical International, London, ON, Canada) with a face mask for the inhalation of trial medication. Children aged 5 years at screening were permitted to use the Respimat with or without a spacer and mouthpiece, depending on preference.

\section{End-points}

The assessment of safety (together with efficacy) was a primary objective in all five trials. In the four trials in children aged 6-17 years, the primary efficacy end-point was improvement in forced expiratory volume in $1 \mathrm{~s}$ and this is what the power calculations were based on. In the trial involving children aged $<6$ years, there was no formal power calculation related to an end-point, but the recruitment was considered sufficient for the descriptive evaluation of efficacy and safety. This analysis is based on AEs occurring between first drug inhalation and until 30 days after the last dose of trial medication, coded using the Medical Dictionary for Regulatory Activities (MedDRA) version 18.1 (www.meddra.org). Further details and definitions of AEs and serious AEs (SAEs) can be found in the supplementary material.

A composite end-point, grouping all AEs relating to the MedDRA-preferred term group "asthma exacerbations and asthma-related symptoms", from all studies in the pooled analysis was also analysed. Preferred terms included in this analysis are listed in supplementary table E1.

TABLE 2 Overview of baseline demographics and disease characteristics: treated set

\begin{tabular}{|c|c|c|c|c|c|}
\hline & $\begin{array}{c}\text { NinoTinA-asthma } \\
{[23]}\end{array}$ & $\begin{array}{c}\text { CanoTinA-asthma } \\
{[21]}\end{array}$ & $\begin{array}{c}\text { VivaTinA-asthma } \\
{[20]}\end{array}$ & $\begin{array}{c}\text { RubaTinA-asthma } \\
{[17]}\end{array}$ & $\begin{array}{c}\text { PensieTinA-asthma } \\
{[18]}\end{array}$ \\
\hline Subjects & 101 & 401 & 400 & 397 & 392 \\
\hline Age years & $3.0(1-5)$ & $9.0(6-11)$ & $9.0(6-11)$ & $14.0(11-17)$ & $14.0(12-17)$ \\
\hline \multicolumn{6}{|l|}{ Race } \\
\hline White & $77(76.2)$ & $339(84.5)$ & $358(89.5)$ & 368 (92.7) & $371(94.6)$ \\
\hline $\begin{array}{l}\text { American Indian/Alaska } \\
\text { Native }\end{array}$ & 0 & 45 (11.2) & $35(8.8)$ & $2(0.5)$ & $3(0.8)$ \\
\hline Hawaiian/Pacific Islander & 0 & 0 & 0 & 0 & 0 \\
\hline \multicolumn{6}{|l|}{ Ethnicity } \\
\hline Hispanic/Latino & 0 & 55 (13.7) & $72(18.0)$ & $42(10.6)$ & 68 (17.3) \\
\hline Never-smoker & & & & 396 (99.7) & $392(100)$ \\
\hline \multicolumn{6}{|l|}{ Concomitant diagnoses } \\
\hline Allergic rhinitis & $20(19.8)$ & $230(57.4)$ & 238 (59.5) & $219(55.2)$ & 225 (57.4) \\
\hline Atopic dermatitis & $17(16.8)$ & 55 (13.7) & $38(9.5)$ & $37(9.3)$ & $38(9.7)$ \\
\hline FEV $_{1} \%$ pred & & $84.06 \pm 10.79$ & $81.64 \pm 11.45$ & $82.79 \pm 10.56$ & $79.52 \pm 11.49$ \\
\hline FEV $1 \%$ reversibility & & $26.48 \pm 12.41$ & $27.43 \pm 13.43$ & $26.80 \pm 12.86$ & $29.19 \pm 14.26$ \\
\hline ACQ score $\#$ & & $1.868 \pm 0.31$ & $1.966 \pm 0.36$ & $2.03 \pm 0.43$ & $2.13 \pm 0.43$ \\
\hline \multicolumn{6}{|l|}{$\begin{array}{l}\text { Concomitant therapies at } \\
\text { baseline }\end{array}$} \\
\hline LTRAs & $41(40.6)$ & 107 (26.7) & 339 (84.8) & 33 (8.3) & 315 (80.4) \\
\hline LABAs & $8(7.9)$ & $1(0.2)$ & 313 (78.3) & $1(0.3)$ & 324 (82.7) \\
\hline $\begin{array}{l}\text { ICS dose of stable } \\
\text { maintenance treatment } \\
\mu \mathrm{g} \cdot \text { day }^{-1} \text { budesonide or } \\
\text { equivalent }\end{array}$ & $255.2 \pm 187.4$ & $310.0 \pm 112.0$ & $457.4 \pm 236.0$ & $539.4 \pm 292.7$ & $747.0 \pm 357.7$ \\
\hline
\end{tabular}

Data are presented as $\mathrm{n}, \mathrm{n}(\%)$, median (range) or mean士SD. FEV1: forced expiratory volume in $1 \mathrm{~s} ; \%$ pred: \% predicted; ACQ: Asthma Control Questionnaire; LTRA: leukotriene receptor antagonist; LABA: long-acting $\beta_{2}$-agonist; ICS: inhaled corticosteroid. \#: interviewer-administered ACQ in CanoTinA-asthma and VivaTinA-asthma. 
Pooled safety data are presented for the following analysis groups: all patients, and subgroups by age, asthma severity and sex.

Additionally, the number of AEs related to asthma exacerbations and symptoms in the pooled data were plotted by month, with data from the Southern hemisphere shifted by 6 months to align the seasons (Northern hemisphere: June=month 6; Southern hemisphere: December=month 6).

Analyses were performed on the treated set, defined as all randomised patients who received at least one dose of trial medication. Analyses were evaluated descriptively and no inferential statistics were performed. Analysis of AEs related to asthma exacerbations and symptoms in the pooled data were plotted by month as a post hoc analysis and therefore considered exploratory only.

As has been reported, each study was conducted in accordance with the amended Declaration of Helsinki. The ethics research boards of the respective institutions approved the protocols, and signed, informed consent was obtained from all patients and/or their parents. See original publications for further details $[18,19,21-23]$.

\section{Results}

A total of 1691 patients comprised the treated set (table 2): 560 patients received tiotropium $5 \mu \mathrm{g}, 559$ patients received tiotropium $2.5 \mu \mathrm{g}$ and 572 patients received placebo. Overall, the mean exposure to study medication was 314,304 and 314 patient-years with tiotropium $5 \mu \mathrm{g}$, tiotropium $2.5 \mu \mathrm{g}$ and placebo, respectively.

\section{Safety}

The overall number of patients with AEs was generally comparable between treatment groups, including placebo (table 3). Approximately half of the patients $(n=879(52 \%))$ experienced at least one AE $(n=283$ (51\%) receiving tiotropium $5 \mu \mathrm{g} ; \mathrm{n}=286$ (51\%) receiving tiotropium $2.5 \mu \mathrm{g} ; \mathrm{n}=310$ (54\%) receiving placebo). Very few AEs led to treatment discontinuation: two in patients receiving tiotropium $5 \mu \mathrm{g}$ and five in patients receiving placebo. The only AE leading to discontinuation reported for more than one patient was asthma exacerbation/worsening (two patients receiving tiotropium $5 \mu \mathrm{g}$ and two patients receiving placebo). The incidence of patients with investigator-defined drug-related AEs was low and comparable between treatment groups, including placebo. None of the drug-related AEs in the tiotropium treatment groups were serious or led to treatment discontinuation. The only AE assessed as drug related that was reported in more than two patients was cough (one patient receiving tiotropium $5 \mu \mathrm{g}$; one patient receiving tiotropium $2.5 \mu \mathrm{g}$; four patients receiving placebo). The overall frequency of patients that experienced SAEs was low and comparable between treatment groups. No SAEs were considered drug related or led to treatment discontinuation. The only SAEs reported for more than two patients were asthma exacerbation/worsening/crisis (five patients receiving tiotropium $5 \mu \mathrm{g}$; three patients receiving tiotropium $2.5 \mu \mathrm{g}$; five patients receiving placebo) and appendicitis (two patients receiving tiotropium $5 \mu \mathrm{g}$; two patients receiving tiotropium $2.5 \mu \mathrm{g}$; one patient receiving placebo). No deaths occurred during any of the trials.

Consistent with the disease profile, the most frequently reported AEs, reported by $\geqslant 5 \%$ of patients, were asthma exacerbation/worsening, decreased peak expiratory flow (PEF) rate, nasopharyngitis/rhinopharyngitis

\begin{tabular}{|c|c|c|c|}
\hline & Tiotropium $5 \mu \mathrm{g}$ & Tiotropium $2.5 \mu \mathrm{g}$ & Placebo \\
\hline Subjects & 560 & 559 & 572 \\
\hline Any AEs & $283(50.5)$ & $286(51.2)$ & $310(54.2)$ \\
\hline Drug-related AEs & 7 (1.3) & $1(0.2)$ & $8(1.4)$ \\
\hline AEs leading to discontinuation & $2(0.4)$ & 0 & $5(0.9)$ \\
\hline Serious AEs & $10(1.8)$ & $8(1.4)$ & $13(2.3)$ \\
\hline \multicolumn{4}{|l|}{ AEs reported in $\geqslant 5 \%$ and $\geqslant 10$ patients $\#$} \\
\hline Asthma exacerbation/worsening & $110(19.6)$ & $115(20.6)$ & $143(25.0)$ \\
\hline Decreased peak expiratory flow rate & 55 (9.8) & $64(11.4)$ & 68 (11.9) \\
\hline Nasopharyngitis/rhinopharyngitis & 44 (7.9) & $46(8.2)$ & $49(8.6)$ \\
\hline Viral respiratory tract infection & $27(4.8)$ & $24(4.3)$ & $30(5.2)$ \\
\hline
\end{tabular}

Data are presented as $\mathrm{n}$ or $\mathrm{n}(\%)$. Percentages are calculated using total number of patients per treatment as the denominator. ${ }^{\#}$ : in at least one treatment group. 
and viral respiratory tract infection (table 3 ; AEs reported by $\geqslant 2 \%$ of patients are shown in supplementary table E2). These were reported by a similar proportion of patients in the tiotropium and placebo groups, except asthma exacerbation/worsening, which was reported by fewer patients in the tiotropium treatment groups.

The frequency of patients reporting a composite end-point, grouping all AEs related to asthma exacerbations and asthma symptoms, was lower in the tiotropium treatment groups than with placebo (placebo: 217 patients with event (37.9\%); tiotropium $5 \mu \mathrm{g}$ : 177 patients with event $(31.6 \%)$, rate ratio over placebo 0.76 (95\% CI 0.63-0.93); tiotropium $2.5 \mu \mathrm{g}$ : 195 patients with event (34.9\%), rate ratio over placebo 0.87 (95\% CI $0.72-1.05))$. A description of safety topics of interest is available in the supplementary material.

\section{Subgroups by age}

Safety in the different age categories was generally comparable with the pooled population (table 4). The lower proportion of patients with asthma exacerbation/worsening as an $\mathrm{AE}$ in the tiotropium groups compared with the placebo group was most prominently observed in patients aged 1-5 years (6.5\% for tiotropium $5 \mu \mathrm{g} ; 13.9 \%$ for tiotropium $2.5 \mu \mathrm{g} ; 29.4 \%$ for placebo), with similar trends in patients aged 6-11 years (26.4\% for tiotropium $5 \mu \mathrm{g} ; 25.5 \%$ for tiotropium $2.5 \mu \mathrm{g} ; 32.8 \%$ for placebo) and $12-17$ years ( $14.4 \%$ for tiotropium $5 \mu \mathrm{g} ; 16.3 \%$ for tiotropium $2.5 \mu \mathrm{g} ; 16.8 \%$ for placebo).

No SAEs were reported in patients treated with tiotropium in the 1-5-year-old group and no AEs in this age group led to discontinuation in any treatment group (table 4; SAEs by age are shown in supplementary table E3). Asthma was the only AE preferred term reported in $\geqslant 5 \%$, or in 10 or more patients, in any of the treatment groups.

An analysis of pooled data from studies with patients aged $\geqslant 6$ years is detailed in supplementary table E4.

TABLE 4 Overview of patients reporting adverse events (AEs) by age subgroups: treated set (treatment plus 30 days following treatment)

Tiotropium $5 \mu \mathrm{g}$

Tiotropium $2.5 \mu \mathrm{g}$

Placebo

\begin{tabular}{|c|c|c|c|}
\hline \multicolumn{4}{|l|}{ Age $1-5$ years $[23]$} \\
\hline Subjects & 31 & 36 & 34 \\
\hline Any AEs & $18(58.1)$ & $20(55.6)$ & $25(73.5)$ \\
\hline Drug-related AEs & $2(6.5)$ & $\begin{array}{l}0 \\
0\end{array}$ & $2(5.9)$ \\
\hline AEs leading to discontinuation & 0 & 0 & 0 \\
\hline Serious AEs & 0 & 0 & $3(8.8)$ \\
\hline \multicolumn{4}{|l|}{ AEs reported in $\geqslant 5 \%$ and $\geqslant 10$ patients $\#$} \\
\hline Asthma exacerbation/worsening & $2(6.5)$ & 5 (13.9) & $10(29.4)$ \\
\hline \multicolumn{4}{|l|}{ Age $6-11$ years $[21,22]$} \\
\hline Subjects & 265 & 271 & 265 \\
\hline Any AEs & $138(52.1)$ & $145(53.5)$ & 155 (58.5) \\
\hline Drug-related AEs & $1(0.4)$ & 0 & $4(1.5)$ \\
\hline AEs leading to discontinuation & $2(0.8)$ & 0 & $2(0.8)$ \\
\hline Serious AEs & $5(1.9)$ & $5(1.8)$ & $8(3.0)$ \\
\hline \multicolumn{4}{|l|}{ AEs reported in $\geqslant 5 \%$ and $\geqslant 10$ patients $\#$} \\
\hline Asthma exacerbation/worsening & $70(26.4)$ & $69(25.5)$ & $87(32.8)$ \\
\hline Decreased peak expiratory flow rate & $44(16.6)$ & $46(17.0)$ & $47(17.7)$ \\
\hline Nasopharyngitis/rhinopharyngitis & $18(6.8)$ & $21(7.7)$ & $24(9.1)$ \\
\hline \multicolumn{4}{|l|}{ Age $12-17$ years $[18,19]$} \\
\hline Subjects & 264 & 252 & 273 \\
\hline Any AEs & $127(48.1)$ & $121(48.0)$ & $130(47.6)$ \\
\hline Drug-related AEs & $4(1.5)$ & $1(0.4)$ & $2(0.7)$ \\
\hline AEs leading to discontinuation & 0 & 0 & $3(1.1)$ \\
\hline Serious AEs & 5 (1.9) & $3(1.2)$ & $2(0.7)$ \\
\hline \multicolumn{4}{|l|}{ AEs reported in $\geqslant 5 \%$ and $\geqslant 10$ patients $\#$} \\
\hline Asthma exacerbation/worsening & $38(14.4)$ & $41(16.3)$ & $46(16.8)$ \\
\hline Nasopharyngitis/rhinopharyngitis & $24(9.1)$ & $18(7.1)$ & $20(7.3)$ \\
\hline Decreased peak expiratory flow rate & $11(4.2)$ & $18(7.1)$ & $21(7.7)$ \\
\hline Viral respiratory tract infection & $11(4.2)$ & $11(4.4)$ & $14(5.1)$ \\
\hline
\end{tabular}

Data are presented as $\mathrm{n}$ or $\mathrm{n}(\%)$. Percentages are calculated using total number of patients per treatment as the denominator. ${ }^{\#}$ : in at least one treatment group. 


\begin{tabular}{|c|c|c|c|}
\hline & Tiotropium $5 \mu \mathrm{g}$ & Tiotropium $2.5 \mu \mathrm{g}$ & Placebo \\
\hline \multicolumn{4}{|l|}{ Moderate asthma $[18,22]$} \\
\hline Subjects & 269 & 260 & 269 \\
\hline Any AEs & $166(61.7)$ & $165(63.5)$ & $171(63.6)$ \\
\hline Drug-related AEs & $4(1.5)$ & $1(0.4)$ & $3(1.1)$ \\
\hline AEs leading to discontinuation & 0 & 0 & $2(0.7)$ \\
\hline Serious AEs & $4(1.5)$ & $5(1.9)$ & $8(3.0)$ \\
\hline \multicolumn{4}{|l|}{ AEs reported in $\geqslant 5 \%$ and $\geqslant 10$ patients $\#$} \\
\hline Asthma exacerbation/worsening & $69(25.7)$ & $76(29.2)$ & $89(33.1)$ \\
\hline Decreased peak expiratory flow rate & 35 (13.0) & $40(15.4)$ & 35 (13.0) \\
\hline Nasopharyngitis/rhinopharyngitis & $31(11.5)$ & $28(10.8)$ & $30(11.2)$ \\
\hline Viral respiratory tract infection & $18(6.7)$ & $19(7.3)$ & $19(7.1)$ \\
\hline Respiratory tract infection & $15(5.6)$ & $16(6.2)$ & $21(7.8)$ \\
\hline \multicolumn{4}{|l|}{ Severe asthma $[19,21]$} \\
\hline Subjects & 260 & 263 & 269 \\
\hline Any AEs & $99(38.1)$ & $101(38.4)$ & $114(42.4)$ \\
\hline Drug-related AEs & $1(0.4)$ & 0 & $3(1.1)$ \\
\hline AEs leading to discontinuation & $2(0.8)$ & 0 & $3(1.1)$ \\
\hline Serious AEs & $6(2.3)$ & $3(1.1)$ & $2(0.7)$ \\
\hline \multicolumn{4}{|l|}{ AEs reported in $\geqslant 5 \%$ and $\geqslant 10$ patients $\#$} \\
\hline Asthma exacerbation/worsening & $39(15.0)$ & $34(12.9)$ & $44(16.4)$ \\
\hline Decreased peak expiratory flow rate & $20(7.7)$ & $24(9.1)$ & 33 (12.3) \\
\hline Nasopharyngitis/rhinopharyngitis & $11(4.2)$ & $11(4.2)$ & $14(5.2)$ \\
\hline
\end{tabular}

Data are presented as $\mathrm{n}$ or $\mathrm{n}(\%)$. Percentages are calculated using total number of patients per treatment as the denominator. ${ }^{\#}$ : in at least one treatment group.

\section{Subgroups by asthma severity}

The safety in the different asthma severity categories was generally comparable with the pooled population (table 5). However, compared with the pooled population, more patients with moderate asthma reported at least one $\mathrm{AE}$ and fewer patients with severe asthma reported at least one AE. This is most likely due to the longer duration of the studies in moderate asthma (48 weeks for moderate asthma versus 12 weeks for severe asthma). Of note, in patients with severe asthma, decreased PEF rate was reported by fewer patients in the tiotropium groups than in the placebo group.

Subgroup analyses of LABA and LTRA use at randomisation were also performed; as expected, the results were consistent with the subgroup analyses by severity, since LABAs/LTRAs were predominantly taken by patients with more severe asthma.

\section{Subgroups by sex}

In an analysis of AEs by sex, there were fewer females than males in each treatment group; proportionally, slightly fewer females reported AEs compared with males, particularly in the tiotropium $5 \mu \mathrm{g}$ and placebo groups, with no notable differences in the proportion of patients with drug-related AEs or AEs leading to discontinuation (table 6). As in the overall analysis, the frequency of patients experiencing SAEs was low and comparable between treatment groups.

\section{Analysis of seasonal asthma worsening}

When analysed by month, reports of AEs related to asthma exacerbations and symptoms were greatest in the placebo group in the spring, autumn and winter (figure 1), and lowest in the summer. With both doses of tiotropium, spring and autumn peaks were reduced. An analysis by month of reported AEs relating to asthma exacerbations and symptoms from studies with patients aged $\geqslant 6$ years is detailed in supplementary figure E1.

\section{Discussion}

In this comprehensive pooled analysis, tiotropium was well tolerated, with a safety profile comparable with placebo. Specifically, the incidence of patients reporting drug-related AEs, AEs leading to discontinuation, SAEs and AEs commonly associated with anticholinergic therapy was low and generally balanced between treatment groups, including placebo. Baseline demographics and disease characteristics were comparable between the treatment groups within each trial (table 2). Pharmacokinetic data from the 1-5-year-old 


\begin{tabular}{|c|c|c|c|}
\hline & Tiotropium $5 \mu \mathrm{g}$ & Tiotropium $2.5 \mu \mathrm{g}$ & Placebo \\
\hline \multicolumn{4}{|l|}{ Males } \\
\hline Subjects & 365 & 373 & 366 \\
\hline Any AEs & $195(53.4)$ & $190(50.9)$ & 201 (54.9) \\
\hline Drug-related AEs & $5(1.4)$ & 0 & $5(1.4)$ \\
\hline AEs leading to discontinuation & $2(0.5)$ & 0 & $3(0.8)$ \\
\hline Serious AEs & $7(1.9)$ & $6(1.6)$ & $4(1.1)$ \\
\hline \multicolumn{4}{|l|}{ AEs reported in $\geqslant 5 \%$ and $\geqslant 10$ patients $\#$} \\
\hline Asthma exacerbation/worsening & 75 (20.5) & $73(19.6)$ & $94(25.7)$ \\
\hline Decreased peak expiratory flow rate & $38(10.4)$ & $49(13.1)$ & $44(12.0)$ \\
\hline Nasopharyngitis/rhinopharyngitis & $29(7.9)$ & $34(9.1)$ & $34(9.3)$ \\
\hline Viral respiratory tract infection & $16(4.4)$ & $14(3.8)$ & $22(6.0)$ \\
\hline Respiratory tract infection & $14(3.8)$ & $11(2.9)$ & $20(5.5)$ \\
\hline \multicolumn{4}{|l|}{ Females } \\
\hline Subjects & 195 & 186 & 206 \\
\hline Any AEs & $88(45.1)$ & $96(51.6)$ & $109(52.9)$ \\
\hline Drug-related AEs & $2(1.0)$ & $1(0.5)$ & $3(1.5)$ \\
\hline AEs leading to discontinuation & 0 & 0 & $2(1.0)$ \\
\hline Serious AEs & $3(1.5)$ & $2(1.1)$ & $9(4.4)$ \\
\hline \multicolumn{4}{|l|}{ AEs reported in $\geqslant 5 \%$ and $\geqslant 10$ patients $\#$} \\
\hline Asthma exacerbation/worsening & 35 (17.9) & $42(22.6)$ & 49 (23.8) \\
\hline Decreased peak expiratory flow rate & $17(8.7)$ & $15(8.1)$ & $24(11.7)$ \\
\hline Nasopharyngitis/rhinopharyngitis & $15(7.7)$ & $12(6.5)$ & $15(7.3)$ \\
\hline Viral respiratory tract infection & $11(5.6)$ & $10(5.4)$ & $8(3.9)$ \\
\hline
\end{tabular}

Data are presented as $\mathrm{n}$ or $\mathrm{n}(\%)$. Percentages are calculated using total number of patients per treatment as the denominator. ${ }^{\#}$ : in at least one treatment group.

group (including those using the valved holding chamber) have previously been shown to be comparable with results from 6-17-year-old groups when adjusted for body size, indicating adequacy of systemic exposure to tiotropium [29].

Efficacy data suggest that tiotropium is an effective add-on to ICS, with or without additional controller therapies, in children and adolescents with asthma [16-19, 22, 23]. The results of this pooled analysis provide additional evidence of the favourable safety profile of tiotropium in children and adolescents with symptomatic asthma (aged 1-17 years) [28, 29].

An important finding is that AEs related to asthma symptoms and exacerbations were reported by fewer patients in the tiotropium $5 \mu \mathrm{g}$ treatment group compared with the placebo, with particular effect in reducing spring and autumn seasonal peaks. While reported as a safety parameter, this signal may also be considered in terms of efficacy, particularly in very young children with asthma, where validated tools for the assessment of efficacy in clinical trials are currently limited [23]. It is interesting to note that this effect
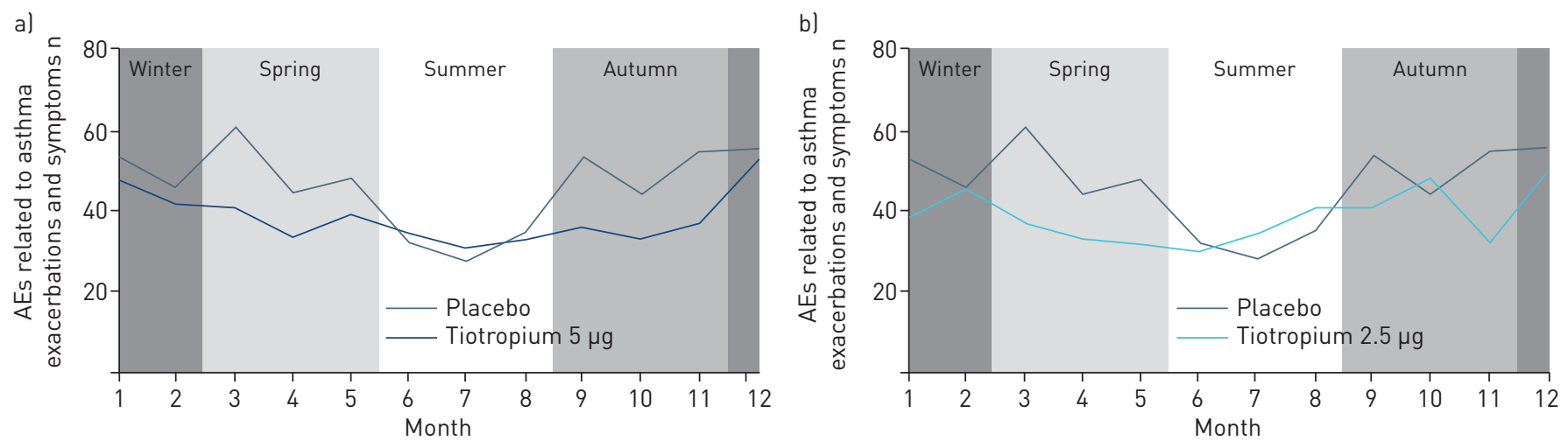

FIGURE 1 Number of reported adverse events (AEs) related to asthma exacerbations and symptoms over 12 months in the pooled population. a) Tiotropium $5 \mu \mathrm{g}$ and placebo groups. b) Tiotropium $2.5 \mu \mathrm{g}$ and placebo groups. Data from the Southern hemisphere shifted by 6 months to align the seasons (Northern hemisphere: June=month 6; Southern hemisphere: December=month 6). 
with tiotropium added to ICS/LABA has been observed with other interventions, including ICS/LABA combinations [30] and biologicals [31]. As long-term asthma exacerbation trials in paediatric patients remain ethically challenging, this analysis highlights an alternative end-point to investigate such efficacy in children. These data also highlight the importance of trial timing to account for seasonal exacerbation peaks when a 12-month study length is not practical. However, since this finding is exploratory, it should be confirmed in a predefined study that could also investigate which age subgroup had the greatest benefit.

Reported class effects of anticholinergics include upper respiratory tract infections, tachycardia, dry mouth and other gastrointestinal complications, as well as urinary retention and urinary tract infections [32-35]. The incidence of patients reporting these AEs was low in the present analysis and, overall, the safety profile of tiotropium was comparable with placebo in all trials reported here [29]. Notably, cardiac events were reported by only two patients and they were both in the placebo group.

Within analyses of population subgroups defined by age, asthma severity, sex and LABA/LTRA use at baseline, the proportions of patients reporting AEs and SAEs were generally comparable between treatment groups, including placebo. This is further supported by a recent systematic review of the efficacy and safety of tiotropium in children aged 6-11 years with symptomatic moderate-to-severe asthma [36]. The authors concluded that none of the three studies included in the analysis (two of which are included in the analysis presented here) showed an increase in the rate of AEs or SAEs reported in the tiotropium group compared with placebo [36].

A major strength of this analysis is that all the trials were placebo controlled with comparable design and therefore provide the most valid comparison for assessing AEs. Furthermore, all patients continued to receive their usual maintenance therapies (except for LABA in patients with moderate asthma), allowing investigation of tiotropium in varied settings of concurrent medications and thereby making it as representative of treatment in a real-world setting as is achievable in a clinical trial setting. The patient sample was very large and covered a wide age range; patients were recruited from various populations and geographical locations, including a high proportion of Latin American patients (a population noted to have a high incidence and a higher severity of childhood asthma). Limitations of our pooled analysis included the difference in duration of the five included trials (two at 48 weeks and three at 12 weeks) and that none were $>48$ weeks.

\section{Conclusions}

Once-daily tiotropium as add-on to at least ICS maintenance treatment in patients aged 1-17 years with symptomatic asthma at different GINA treatment steps is an addition to current treatment options, with a safety and tolerability profile comparable with that of placebo. No new safety signals were identified in this comprehensive analysis, which supports the favourable risk-benefit profile of once-daily tiotropium as add-on to maintenance ICS with or without additional controllers in paediatric patients with symptomatic asthma. Moreover, a reduction in patients reporting AEs related to asthma exacerbations and asthma symptoms was observed with tiotropium $5 \mu \mathrm{g}$, especially related to seasonal peaks in exacerbations.

Acknowledgements: The authors take full responsibility for the scope, direction, content of and editorial decisions relating to the manuscript, were involved at all stages of development, and have approved the submitted manuscript. All authors had full access to all of the data in the study, and take responsibility for the integrity of the data and the accuracy of the data analysis, including and especially any adverse effects. This work was supported financially by Boehringer Ingelheim. Medical writing assistance, in the form of the preparation and revision of the manuscript, was supported financially by Boehringer Ingelheim and provided by Jonathan Brennan (MediTech Media, Manchester, UK) under the authors' conceptual direction and based on feedback from the authors. The authors would like to thank all the patients and their families for participating in these trials, and they also extend their thanks to the investigators.

Author contributions: M. Engel and P.M. Moroni-Zentgraf were involved in the study design, data analysis and interpretation. G. El Azzi and S.D. Vulcu were involved in the data analysis and interpretation. All authors were involved in the writing of the manuscript and the decision to submit the manuscript for publication.

Conflict of interest: C. Vogelberg reports study-related institutional payments from Boehringer Ingelheim, during the conduct of the study; personal fees for advisory board work and lecturing from Boehringer Ingelheim and Novartis, outside the submitted work. S.J. Szefler reports institutional funds for consultancy from Boehringer Ingelheim, Aerocrine, Novartis, Daiichi Sankyo and Roche, institutional funds for manuscript preparation and advisory board work from Genentech, research grants and institutional funds for meeting attendance and advisory board work from GlaxoSmithKline, institutional funds for educational activities from AstraZeneca, institutional funds for advisory board work from Teva, outside the submitted work. E.J.L.E. Vrijlandt has nothing to disclose. A.L. Boner has nothing to disclose. M. Engel is an employee of Boehringer Ingelheim. G. El Azzi was employed by Boehringer Ingelheim, during the conduct of the study. S.D. Vulcu is an employee of Boehringer Ingelheim. P.M. Moroni-Zentgraf is an employee of Boehringer Ingelheim. O. Eickmeier reports compensation for conducting the study from Boehringer Ingelheim International GmbH. E. Hamelmann has consulted for Allergopharma, ALK, Bencard, Boehringer Ingelheim, GlaxoSmithKline, HAL Allergy, Novartis, Nutricia, and Stallergenes; he has received research support from the German Society of Research, the State Ministry of Education and Research of Nordrhein-Westfalen, and the German Ministry of Education and Research. 
Support statement: This work was supported by Boehringer Ingelheim International GmbH (Ingelheim am Rhein, Germany). Medical writing assistance was contracted and compensated by Boehringer Ingelheim International $\mathrm{GmbH}$. Funding information for this article has been deposited with the Crossref Funder Registry.

\section{References}

1 Masoli M, Fabian D, Holt S, et al. The global burden of asthma: executive summary of the GINA Dissemination Committee report. Allergy 2004; 59: 469-478.

2 Schmier JK, Manjunath R, Halpern MT, et al. The impact of inadequately controlled asthma in urban children on quality of life and productivity. Ann Allergy Asthma Immunol 2007; 98: 245-251.

3 Asthma UK. Asthma facts and FAQs. 2016. www.asthma.org.uk/about/media/facts-and-statistics Date last accessed: January 24, 2018.

4 Global Initiative for Asthma. Global Strategy for Asthma Management and Prevention. 2018. https://ginasthma. org/wp-content/uploads/2018/04/wms-GINA-2018-report-V1.3-002.pdf Date last accessed: April 4, 2019.

5 Zhang L, Prietsch SO, Ducharme FM. Inhaled corticosteroids in children with persistent asthma: effects on growth. Evid Based Child Health 2014; 9: 829-930.

6 Kelly HW, Sternberg AL, Lescher R, et al. Effect of inhaled glucocorticoids in childhood on adult height. $N$ Engl J Med 2012; 367: 904-912.

7 Cazzola M, Page CP, Rogliani P, et al. Beta2-agonist therapy in lung disease. Am J Respir Crit Care Med 2013; 187: 690-696.

8 Hon KL, Leung TF, Leung AK. Clinical effectiveness and safety of montelukast in asthma. What are the conclusions from clinical trials and meta-analyses? Drug Des Devel Ther 2014; 8: 839-850.

9 Brunlof G, Tukukino C, Wallerstedt SM. Individual case safety reports in children in commonly used drug groups - signal detection. BMC Clin Pharmacol 2008; 8: 1.

10 Haarman MG, van Hunsel F, de Vries TW. Adverse drug reactions of montelukast in children and adults. Pharmacol Res Perspect 2017; 5: e00341.

11 Ohta K, Ichinose M, Tohda Y, et al. Long-term once-daily tiotropium Respimat is well tolerated and maintains efficacy over 52 weeks in patients with symptomatic asthma in Japan: a randomised, placebo-controlled study. PLoS One 2015; 10: e0124109.

12 Kerstjens HA, Casale TB, Bleecker ER, et al. Tiotropium or salmeterol as add-on therapy to inhaled corticosteroids for patients with moderate symptomatic asthma: two replicate, double-blind, placebo-controlled, parallel-group, active-comparator, randomised trials. Lancet Respir Med 2015; 3: 367-376.

13 Paggiaro P, Halpin DM, Buhl R, et al. The effect of tiotropium in symptomatic asthma despite low- to medium-dose inhaled corticosteroids: a randomized controlled trial. J Allergy Clin Immunol Pract 2016; 4: 104-113.

14 Beeh KM, Moroni-Zentgraf P, Ablinger O, et al. Tiotropium Respimat in asthma: a double-blind, randomised, dose-ranging study in adult patients with moderate asthma. Respir Res 2014; 15: 61.

15 Timmer W, Moroni-Zentgraf P, Cornelissen P, et al. Once-daily tiotropium Respimat $5 \mu \mathrm{g}$ is an efficacious 24-h bronchodilator in adults with symptomatic asthma. Respir Med 2015; 109: 329-338.

16 Vogelberg C, Engel M, Moroni-Zentgraf P, et al. Tiotropium in asthmatic adolescents symptomatic despite inhaled corticosteroids: a randomised dose-ranging study. Respir Med 2014; 108: 1268-1276.

17 Vogelberg C, Moroni-Zentgraf P, Leonaviciute-Klimantaviciene M, et al. A randomised dose-ranging study of tiotropium Respimat in children with symptomatic asthma despite inhaled corticosteroids. Respir Res 2015; 16: 20.

18 Hamelmann E, Bateman ED, Vogelberg C, et al. Tiotropium add-on therapy in adolescents with moderate asthma: a 1-year randomized controlled trial. J Allergy Clin Immunol 2016; 138: 441-450.

19 Hamelmann E, Bernstein JA, Vandewalker M, et al. A randomised controlled trial of tiotropium in adolescents with severe symptomatic asthma. Eur Respir J 2017; 49: 1601100.

20 Kerstjens HA, Disse B, Schroder-Babo W, et al. Tiotropium improves lung function in patients with severe uncontrolled asthma: a randomized controlled trial. J Allergy Clin Immunol 2011; 128: 308-314.

21 Szefler SJ, Murphy K, Harper T, et al. A phase III randomized controlled trial of tiotropium add-on therapy in children with severe symptomatic asthma. J Allergy Clin Immunol 2017; 140: 1277-1287.

22 Vogelberg C, Engel M, Laki I, et al. Tiotropium add-on therapy improves lung function in children with symptomatic moderate asthma. J Allergy Clin Immunol Pract 2018; 6: 2160-2162.

23 Vrijlandt EJLE, El Azzi G, Vandewalker M, et al. Safety and efficacy of tiotropium in children aged 1-5 years with persistent asthmatic symptoms: a randomised, double-blind, placebo-controlled trial. Lancet Respir Med 2018; 6: $127-137$.

24 Kerstjens HA, Engel M, Dahl R, et al. Tiotropium in asthma poorly controlled with standard combination therapy. N Engl J Med 2012; 367: 1198-1207.

25 US Food and Drug Administration. Prescribing information for Spiriva Respimat (tiotropium bromide) inhalation spray, for oral inhalation. 2017. www.accessdata.fda.gov/drugsatfda_docs/label/2017/021936s007lbl.pdf Date last updated: February 16, 2017. Date last accessed: October 22, 2018.

26 Boehringer Ingelheim. Asthma: expanded indication for SPIRIVA Respimat for people 6 years and older. 2018. www.boehringer-ingelheim.com/press-release/expanded-asthma-indication-spiriva-respimat-eu Date last accessed: October 22, 2018.

27 Dahl R, Engel M, Dusser D, et al. Safety and tolerability of once-daily tiotropium Respimat as add-on to at least inhaled corticosteroids in adult patients with symptomatic asthma: a pooled safety analysis. Respir Med 2016; 118: $102-111$.

28 Hamelmann E, Szefler SJ. Efficacy and safety of tiotropium in children and adolescents. Drugs 2018; 78: 327-338.

29 Kerstjens HA, O'Byrne PM. Tiotropium for the treatment of asthma: a drug safety evaluation. Expert Opin Drug Saf 2016; 15: 1115-1124.

30 Spahn J, Sheth K, Yeh WS, et al. Dispensing of fluticasone propionate/salmeterol combination in the summer and asthma-related outcomes in the fall. J Allergy Clin Immunol 2009; 124: 1197-1203.

31 Busse WW, Morgan WJ, Gergen PJ, et al. Randomized trial of omalizumab (anti-IgE) for asthma in inner-city children. N Engl J Med 2011; 364: 1005-1015. 
32 Alagha K, Palot A, Sofalvi T, et al. Long-acting muscarinic receptor antagonists for the treatment of chronic airway diseases. Ther Adv Chronic Dis 2014; 5: 85-98.

33 Bateman E, Singh D, Smith D, et al. Efficacy and safety of tiotropium Respimat SMI in COPD in two 1-year randomized studies. Int J Chron Obstruct Pulmon Dis 2010; 5: 197-208.

34 Singh S, Loke YK, Furberg CD. Inhaled anticholinergics and risk of major adverse cardiovascular events in patients with chronic obstructive pulmonary disease: a systematic review and meta-analysis. JAMA 2008; 300: 1439-1450.

35 Kew KM, Dias S, Cates CJ. Long-acting inhaled therapy (beta-agonists, anticholinergics and steroids) for COPD: a network meta-analysis. Cochrane Database Syst Rev 2014; 3: CD010844.

36 Rodrigo GJ, Neffen H. Efficacy and safety of tiotropium in school-age children with moderate-to-severe symptomatic asthma: a systematic review. Pediatr Allergy Immunol 2017; 28: 573-578. 